\title{
Repeat or persistent Lyme disease: persistence, recrudescence or reinfection with Borrelia Burgdorferi?
}

\author{
Eugene D. Shapiro
}

Address: Departments of Pediatrics, Epidemiology of Microbial Diseases and Investigative Medicine, Yale University Schools of Medicine and of Public Health and Graduate School of Arts and Sciences, New Haven, CT, USA

Email: Eugene.Shapiro@Yale.edu

FI000Prime Reports 2015, 7:II (doi:10.12703/P7-II)

All FI000Prime Reports articles are distributed under the terms of the Creative Commons Attribution-Non Commercial License (http://creativecommons.org/licenses/by-nc/3.0/legalcode), which permits non-commercial use, distribution, and reproduction in any medium, provided the original work is properly cited.

The electronic version of this article is the complete one and can be found at: http://fl000.com/prime/reports/m/7/II

\begin{abstract}
Whether or not Borrelia burgdorferi can persist after conventional treatment with antimicrobials has been a very controversial issue. Two recent studies took different approaches to try to answer this question. In one, investigators showed that, in each of 22 instances in 17 patients with two consecutive episodes of culture-proved erythema migrans, the strains of $B$. burgdorferi were different based on their genotypes. This indicated that the repeat episodes were due to new infections rather than recrudescence of the original infection. In another study, in which persistence of $B$. burgdorferi was assessed by using xenodiagnosis, no viable $B$. burgdorferi were cultured from ticks fed on any of the patients. There continues to be no evidence that viable $B$. burgdorferi persist in humans after conventional treatment with antimicrobials.
\end{abstract}

\section{Introduction}

One of the most contentious issues related to Lyme disease has been whether infection with $B$. burgdorferi can be easily eradicated by conventional antimicrobial treatment or whether it is a persistent, recurrent and difficult to eradicate infection. Post-treatment Lyme disease syndrome refers to patients with persistent, nonspecific symptoms, such as arthralgia, fatigue or perceived cognitive impairment $\geq 6$ months after completion of treatment for Lyme disease. Many of those who believe in a condition termed "chronic Lyme disease" argue that documenting that the bacteria can survive a standard course of antimicrobial treatment will prove that chronic Lyme disease and post-treatment Lyme disease syndrome are indeed a consequence of persistent infection with B. burgdorferi. This belief persists, despite a mountain of scientific evidence that chronic Lyme disease, a label without a case definition that is applied to patients with non-specific symptoms more properly designated "medically unexplained symptoms", does not exist [1-3].
Several studies in which investigators have claimed to have documented persistence of $B$. burgdorferi in humans, despite treatment with antimicrobials, have not been reproduced or have been shown to be due to laboratory contaminants [4-8]. Some studies in which models of the infection in animals (usually in either mice or non-human primates) have been performed have lent support to the argument that B. burgdorferi can persist in tissues despite antimicrobial treatment [9]. However, there are numerous problems with the animal models that have led many to question either the reliability of the results of these studies or the generalizability of the results to disease in humans $[10,11]$. Among the many problems with animal models is the difficulty of mimicking the route and infectious dose of B. burgdorferi in human infection, differences in the pharmacokinetic and pharmacodynamic parameters of antimicrobial treatment in the animals vs. humans, and differences in immune responses of different animal species (for example, mice are reservoirs for B. burgdorferi 
in nature). In addition, even in the rare instances in which B. burgdorferi has been identified in treated animals, it has not been shown to be viable (that is, able to replicate in culture media). Moreover, whether it is producing symptomatic disease in these animals is speculative. Several recent studies have shed additional light on this topic and have added to the evidence that viable $B$. burgdorferi do not persist after antimicrobial treatment of humans.

\section{Recent studies}

Repeat episodes of erythema migrans

It is well recognized that subsequent episodes of erythema migrans are not unusual in patients with an initial episode who receive prompt antimicrobial treatment. If $B$. burgdorferi persist despite antimicrobial treatment, it would make sense that subsequent episodes of erythema migrans might be due to the originally infecting strain of the organism. In a study to assess whether such episodes were new infections or recurrences, strains of $B$. burgdorferi from 17 patients with two or more episodes of culture-proved erythema migrans had 22 paired episodes with organisms available for analysis (first and second episodes, and, for those with additional episodes, third and fourth episodes) [12]. Strains were compared by amplifying their DNA with polymerase chain reaction (PCR) assay of each strain, followed by genotyping of outer surface protein $\mathrm{C}$ of each strain. In all instances, the strains in each of the paired episodes were different, indicating that each of the subsequent episodes of erythema migrans was due to a new infection (presumably transmitted from a new tick bite) rather than recrudescence of a persistent infection $[12,13]$. Moreover, investigators used statistical simulation based on these data to conclude that patients treated for early Lyme disease develop protective immunity that is strain specific and that lasts for at least 6 years [14].

\section{Xenodiagnosis for B. Burgdorferi}

Proponents of the existence of "chronic Lyme disease" postulate that the organism often persists despite conventional treatment with an antimicrobial, and that very prolonged treatment with antimicrobials is necessary to eliminate the organism. However, other than a few isolated claims (that could not be replicated) of recovery of B. burgdorferi from patients with chronic symptoms, there is no evidence that viable organisms persist as a cause of chronic symptoms in humans, despite conventional treatment with antimicrobials [4-8]. In infected patients, $B$. burgdorferi is present only in low concentrations in blood and spinal fluid and can be difficult to culture [15].

Xenodiagnosis is a method of documenting the presence of a microorganism in tissue by allowing a vector to feed on potentially infected tissue and then examining the vector for the presence of the microorganism it may have ingested. In the past, it was used extensively as a method of diagnosing Chagas disease [16]. Some say it may be the most sensitive test in mammals because of evolutionary adaptations of the vector and the microorganism. For example, there is evidence that a chemoattractant is secreted by Ixodes scapularis that can enhance migration of B. burgdorferi to its mouthparts while feeding on a host [17]. I. scapularis ticks have been used successfully for xenodiagnosis in studies with animals [18]. The first use of xenodiagnosis to try to detect $B$. burgdorferi in humans was reported recently [16].

In this study [16], 36 human subjects (median age: 55 years) had 25-30 laboratory-raised, pathogen-free, larval I. scapularis ticks placed on them under a retention dressing and were then collected after feeding for 3 to 7 days. The 36 subjects included 10 patients who had been treated for Lyme disease and still had high concentrations of antibodies against the $\mathrm{C} 6$ peptide of the membrane protein of $B$. burgdorferi, 10 patients treated for Lyme disease who had post-treatment Lyme disease syndrome with continuing symptoms severe enough to impair their normal activities, 5 patients who recently completed antibiotic therapy for erythema migrans, 1 patient early in the course of antibiotic therapy for erythema migrans, and 10 healthy controls. The patients recently treated for erythema migrans were meant potentially to be positive controls, since it was felt to be unethical to delay treatment of infected patients, but it was thought that these patients had the best chance of testing positive by xenodiagnosis. Biopsies of skin at the site where ticks fed and homogenates of the ticks were cultured for B. burgdorferi. Ticks were also tested for DNA of B. burgdorferi by PCR assay and/or by isothermal amplification followed by PCR and electrospray ionization mass spectroscopy. In addition, attempts were made to infect immunodeficient mice by having the potentially infected ticks feed on them or by inoculation of homogenates of fed ticks into the mice.

No viable organisms were recovered from ticks or from skin biopsies from any of the patients. DNA of B. burgdorferi was identified from the ticks of 2 patients. One was the patient who was early on in the course of antibiotic treatment for erythema migrans. The other was one of the patients with post-treatment Lyme disease syndrome.

What do these results mean? Most would say that only a positive culture (recovery of viable organisms) would constitute positive xenodiagnosis. It is well recognized that fragments of DNA of B. burgdorferi can persist for a very long period after successful antibiotic treatment and killing of viable organisms [19]. A positive result of a 
highly sensitive PCR assay of a tick from a patient with post-treatment Lyme disease syndrome certainly is provocative. Can persistence of antigens of organisms killed after antimicrobial treatment lead to prolonged non-specific symptoms? Perhaps persistent (non-viable) fragments of organisms can persist and provoke inflammation that leads to symptoms $[20,21]$. This is a single instance and needs to be replicated. Much more data are needed before any conclusions can be drawn. Certainly the results of this study do not provide evidence for the suppositions that viable $B$. burgdorferi persist after conventional antimicrobial treatment, or suggest that additional clinical trials of prolonged antimicrobial treatment of patients with only non-specific symptoms after Lyme disease are warranted [22].

\section{Abbreviation}

PCR, polymerase chain reaction.

\section{Disclosures}

The author receives royalties from UptoDate.

\section{References}

I. Feder HM, Johnson JB, O'Connell S, Shapiro ED, Steere AC, Wormser GP, Ad Hoc International Lyme Disease Group, Agger WA, Artsob H, Auwaerter P, Dumler JS, Bakken JS, Bockenstedt LK, Green J, Dattwyler RJ, Munoz J, Nadelman RB, Schwartz I, Draper T, McSweegan E, Halperin Jj, Klempner MS, Krause PJ, Mead P, Morshed M, Porwancher R, Radolf JD, Smith RP, Sood S, Weinstein A, Wong SJ et al: A critical appraisal of "chronic Lyme disease". N Engl J Med 2007, 357:1422-30.

2. Lantos PM: Chronic Lyme disease: the controversies and the science. Expert Rev Anti Infect Ther 2011, 9:787-97.

\section{FlOOOPrime \\ RECOMMENDED}

3. Hatcher S, Arroll B: Assessment and management of medically unexplained symptoms. BMJ 2008, 336: I I24-8.

\section{FlOOOPrime \\ RECOMMENDED}

4. Phillips SE, Mattman LH, Hulínská D, Moayad H: A proposal for the reliable culture of Borrelia burgdorferi from patients with chronic Lyme disease, even from those previously aggressively treated. Infection 1998, 26:364-7.

5. Sapi E, Pabbati N, Datar A, Davies EM, Rattelle A, Kuo BA: Improved culture conditions for the growth and detection of Borrelia from human serum. Int J Med Sci 2013, 10:362-76.

6. Marques AR, Stock F, Gill V: Evaluation of a new culture medium for Borrelia burgdorferi. J Clin Microbiol 2000, 38:4239-4I.

\section{FlOOOPrime} RECOMMENDED

7. Johnson, Barbara | B, Pilgard MA, Russell TM: Assessment of new culture method for detection of Borrelia species from serum of lyme disease patients. J Clin Microbiol 2014, 52:72I-4.

\section{FlOOOPrime} RECOMMENDED

8. Klempner MS, Schmid CH, Hu L, Steere AC, Johnson G, McCloud B, Noring $R$, Weinstein $A$ : Intralaboratory reliability of serologic and urine testing for Lyme disease. Am J Med 200I, I 1 0:2 17-9.
9. Embers ME, Barthold SW, Borda JT, Bowers L, Doyle L, Hodzic E, Jacobs MB, Hasenkampf NR, Martin DS, Narasimhan S, PhillippiFalkenstein KM, Purcell JE, Ratterree MS, Philipp MT: Persistence of Borrelia burgdorferi in rhesus macaques following antibiotic treatment of disseminated infection. PLoS ONE 2012, 7:e29914.

\section{FlOOOPrime}

RECOMMENDED

10. Wormser GP, Schwartz I: Antibiotic treatment of animals infected with Borrelia burgdorferi. Clin Microbiol Rev 2009, 22:387-95.

\section{FlOOOPrime}

\section{RECOMMENDED}

II. Lantos PM, Auwaerter PG, Wormser GP: A systematic review of Borrelia burgdorferi morphologic variants does not support a role in chronic Lyme disease. Clin Infect Dis 2014, 58:663-7I.

\section{FlOOOPrime}

\section{RECOMMENDED}

12. Nadelman RB, Hanincová K, Mukherjee P, Liveris D, Nowakowski J, McKenna D, Brisson D, Cooper D, Bittker S, Madison G, Holmgren D, Schwartz I, Wormser GP: Differentiation of reinfection from relapse in recurrent Lyme disease. $N$ Engl J Med 2012, 367:1883-90.

\section{FlOOOPrime}

13. Steere AC: Reinfection versus relapse in Lyme disease. $N$ Engl J Med 20I2, 367:1950-I

14. Khatchikian CE, Nadelman RB, Nowakowski J, Schwartz I, Wormser GP, Brisson D: Evidence for strain-specific immunity in patients treated for early lyme disease. Infect Immun 2014, 82:1408-13.

\section{FlOOOPrime}

15. Wormser GP, Bittker S, Cooper D, Nowakowski J, Nadelman RB, Pavia C: Yield of large-volume blood cultures in patients with early Lyme disease. J Infect Dis 200I, 184:1070-2.

16. Marques A, Telford SR, Turk S, Chung E, Williams C, Dardick K, Krause PJ, Brandeburg C, Crowder CD, Carolan HE, Eshoo MW, Shaw PA, Hu LT: Xenodiagnosis to detect Borrelia burgdorferi infection: a first-in-human study. Clin Infect Dis 2014, 58:937-45.

\section{FlOOOPrime} RECOMMENDED

17. Shih C, Chao L, Yu C: Chemotactic migration of the Lyme disease spirochete (Borrelia burgdorferi) to salivary gland extracts of vector ticks. Am J Trop Med Hyg 2002, 66:616-21.

\section{FlOOOPrime} RECOMMENDED

18. Hua CM, Cheminade Y, Perret J, Weynants V, Lobet Y, Gern L: Early detection of Borrelia burgdorferi sensu lato infection in Balb/ c mice by co-feeding Ixodes ricinus ticks. Int J Med Microbiol 2003, 293:42I-6.

\section{FlOOOPrime}

19. Straubinger RK: PCR-Based quantification of Borrelia burgdorferi organisms in canine tissues over a 500-Day postinfection period. J Clin Microbiol 2000, 38:2191-9.

20. Bockenstedt LK, Radolf JD: Xenodiagnosis for posttreatment Lyme disease syndrome: resolving the conundrum or adding to it? Clin Infect Dis 2014, 58:946-8.

21. Bockenstedt LK, Gonzalez DG, Haberman AM, Belperron AA: Spirochete antigens persist near cartilage after murine Lyme borreliosis therapy. J Clin Invest 2012, 122:2652-60.

22. Wormser GP, Nadelman RB, Schwartz I: The amber theory of Lyme arthritis: initial description and clinical implications. Clin Rheumatol 2012, 31:989-94. 